Cahiers $d u$ MONDE RUSSE

\section{Cahiers du monde russe}

Russie - Empire russe - Union soviétique et États indépendants

$50 / 4 \mid 2009$

Varia

\title{
Brian Davies, Warfare, State and Society on the Black Sea Steppe 1500-1700
}

\section{Brian Boeck}

\section{(2) OpenEdition}

\section{Journals}

Electronic version

URL: https://journals.openedition.org/monderusse/7137

DOI: $10.4000 /$ monderusse. 7137

ISSN: $1777-5388$

\section{Publisher}

Éditions de l'EHESS

\section{Printed version}

Date of publication: 15 December 2009

Number of pages: $768-769$

ISBN: 978-2-7132-2261-0

ISSN: $1252-6576$

\section{Electronic reference}

Brian Boeck, "Brian Davies, Warfare, State and Society on the Black Sea Steppe 1500-1700", Cahiers du monde russe [Online], 50/4 | 2009, Online since 12 January 2011, connection on 03 September 2022. URL: http://journals.openedition.org/monderusse/7137 ; DOl: https://doi.org/10.4000/ monderusse. 7137

This text was automatically generated on 3 September 2022.

All rights reserved 


\title{
Brian Davies, Warfare, State and Society on the Black Sea Steppe $1500-1700$
}

\author{
Brian Boeck
}

\section{REFERENCES}

Brian DAVIES, Warfare, State and Society on the Black Sea Steppe 1500-1700. Londres

- New York: Routledge, 2007, 256 p.

1 This is the kind of book that generations of scholars will consult to learn more about the complexities of Russian expansion. Under one cover it synthesizes vast amounts of information that previously could only be encountered in dozens of specialized publications. For the first time it makes available a comprehensive, multifaceted account of Russia's emergence as a great power in the Black Sea region from 1500 to 1700.

The book cogently and concisely discusses military colonization, warfare, strategy, diplomacy, decision-making, resource mobilization, logistics, provisioning, command and control. A plethora of particularly insightful sections explain how things worked in that era. Readers will delight in descriptions of such diverse topics as how a nomadic cavalryman packed when preparing for a raid or the multiple responsibilities of a Muscovite governor.

3 Numbers are another strong aspect of the book. Davies moves seamlessly from smallscale discussions back to the big picture. Whether discussing salaries of individual officers or outlining the entire state budget for entitlements, his figures are reliable and remarkable. Readers are frequently provided with a clear sense of expansion's cost in blood and treasure. In the case of the Konotop battle, for example, he adroitly corrects the compounded errors of his predecessors. The discussion of Slavic captives on page 24-26 is exemplary. Davies perceptively suggests that though Muscovy collected 
large sums in taxes for the ransom of captives, only modest amounts seem to have regularly been spent on the designated purpose.

The book pays considerable attention to events in Ukraine. Rather than polemicize with partisan accounts, Davies stays clear of acrimonious debates that have sapped the energies of generations of Russian, Polish and Ukrainian scholars. He eruditely chronicles a series of improvisations, mutual misunderstandings, and strategic entanglements that led to costly escalations in Moscow's commitment to maintaining military positions in Ukraine.

5 The sections of the study devoted to Russia's engagement with the Ottoman Empire and Crimea are competent, but somewhat hampered by gaps in the published source base. Davies rightly emphasizes the decisive role of Ukraine in shaping Russia's relations with the Turks after 1654. Events in the lower Volga and North Caucasus in general, and Kabarda in particular, are not covered to any substantial degree here. The author's decision to downplay this region could easily have been justified with the facts about fiscal commitment and military mobilization mustered so effectively elsewhere in the book, but I suspect that this decision had something to do with the fact that other recent studies have amplified discussions of this region's role in Moscow's colonial designs beyond levels that are sustainable in the sources.

6 While recognizing the book as a valuable addition to any library collection, a few criticisms are in order. Specialists will appreciate the author's meticulous attention to detail, but undergraduates may have a difficult time with the book's density. Just on page 119 one encounters over a dozen place names and as many surnames. Some additional comments on the state of the primary sources and the curious patterns in their publication (or lack thereof) would have been very useful to those outside the field of Russian history. In numerous places the reader could benefit from more of the kinds of larger generalizations that are advanced in the conclusion. Because Davies usually refrains from openly criticizing the mistakes of his predecessors, casual readers may not even notice some of his most innovative arguments. For the reader who values substance over style, however, this is clearly the most significant treatment of early modern Russia's engagement with the steppe. 